\title{
Physiological and Biochemical Basis of Faba Bean Breeding for Drought Adaptation-A Review
}

\author{
Md Abdul Muktadir 1,2,3(0, Kedar Nath Adhikari $\left.{ }^{1}{ }^{(}\right)$, Andrew Merchant ${ }^{2}$, \\ Kiflemariam Y. Belachew ${ }^{4,5} \mathbb{D}$, Albert Vandenberg ${ }^{6}$, Frederick L. Stoddard ${ }^{4} \mathbb{C}$ \\ and Hamid Khazaei ${ }^{6, *}$ (1) \\ 1 Plant Breeding Institute, The University of Sydney, Narrabri, NSW 2390, Australia; \\ muktadirgpb@gmail.com (M.A.M.); kedar.adhikari@sydney.edu.au (K.N.A.) \\ 2 Centre for Carbon, Water and Food, The University of Sydney, Camperdown, NSW 2570, Australia; \\ andrew.merchant@sydney.edu.au \\ 3 Pulses Research Centre, Bangladesh Agricultural Research Institute, Gazipur 1701, Bangladesh \\ 4 Department of Agricultural Sciences and Viikki Plant Science Centre, University of Helsinki, PO Box 27, \\ 00014 Helsinki, Finland; kiflemariam.belachew@helsinki.fi (K.Y.B.); frederick.stoddard@helsinki.fi (F.L.S.) \\ 5 Department of Plant Sciences, Bahir Dar University, Bahir Dar 5501, Ethiopia \\ 6 Department of Plant Sciences, 51 Campus Drive, University of Saskatchewan, Saskatoon, SK S7N 5A8, \\ Canada; bert.vandenberg@usask.ca \\ * Correspondence: hamid.khazaei@usask.ca
}

Received: 11 August 2020; Accepted: 4 September 2020; Published: 7 September 2020

\begin{abstract}
Grain legumes are commonly used for food and feed all over the world and are the main source of protein for over a billion people worldwide, but their production is at risk from climate change. Water deficit and heat stress both significantly reduce the yield of grain legumes, and the faba bean is considered particularly susceptible. The genetic improvement of faba bean for drought adaptation (water deficit tolerance) by conventional methods and molecular breeding is time-consuming and laborious, since it depends mainly on selection and adaptation in multiple sites. The lack of high-throughput screening methodology and low heritability of advantageous traits under environmental stress challenge breeding progress. Alternatively, selection based on secondary characters in a controlled environment followed by field trials is successful in some crops, including faba beans. In general, measured features related to drought adaptation are shoot and root morphology, stomatal characteristics, osmotic adjustment and the efficiency of water use. Here, we focus on the current knowledge of biochemical and physiological markers for legume improvement that can be incorporated into faba bean breeding programs for drought adaptation.
\end{abstract}

Keywords: Vicia faba; drought; root; shoot; metabolomics

\section{Introduction}

Among the cultivated grain legume crops, the faba bean (Vicia faba L.) ranked sixth globally in production, with a value of 4.5 Million tonnes from 2.5 Mha in 2019 [1]. The common bean (Phaseolus vulgaris L.) ranked first, followed by the field pea (Pisum sativum L.), chickpea (Cicer arietinum L.), cowpea (Vigna unguiculata (L.) Walp) and lentil (Lens culinaris Medik.), and the global average yield per hectare of the faba bean exceeds all of these other species. The faba bean was one of the first domesticated crops in the Middle East [2] and spread from there eastward to Central Asia, India and China; westward to North Africa and Europe and, in more recent times, to Australia and the Americas [3]. While the wild antecedent of the faba bean is not known [4], carbonised remains dating back to 14,000 B.P. are viewed as examples of its existence [5]. 
Grain legumes provide substantial advantages in cereal-based cropping systems by breaking the life cycles of certain diseases, host-specific nematodes and weed species [6]. Like other grain legumes, faba bean and its symbiotic rhizobacteria fix atmospheric nitrogen in a wide range of conditions. Biological nitrogen fixation provides about $80 \%$ of the plant's nitrogen needs [7], reaching $160 \mathrm{~kg}$ $\mathrm{ha}^{-1}$ [7-9], and about half of the crop's fixed nitrogen content is left in the field after grain harvest. Hence, it is considered important for both its contribution to residual nitrogen in crop rotation [6] and its potential in green manuring [10].

Faba bean seeds have high contents of protein and micronutrients and are also a good source of energy and dietary fibre [11,12]. The average protein content is $29 \%$ [13], ranging from $24 \%$ to $35 \%$ [14], making it one of the most protein-rich pulses (starchy grain legumes). Mature beans are cooked into a stew or paste for human consumption in many countries and are also used as animal feed in many others. In its vegetable form, immature pods are harvested when the seeds are filling, and the young seeds are used as salad or cooked as vegetables. Whole-crop silage can be made from the whole plant and is a way of rescuing value from the crop if, for example, an exceptionally wet autumn prevents a harvest of the dry grain.

Among cultivated grain legumes, the faba bean is considered to be sensitive to water deficit (Figure 1). The faba bean yield in irrigated agriculture is significantly higher than in rainfed systems [15], although the majority of its cultivation lies outside irrigated areas. Yield-based meta-analyses data from 1980 to 2014 indicated that the faba bean yield was reduced by $40 \%$ following a $65 \%$ reduction in water availability, and the loss in yield depended on the cultivar and other environmental conditions [16]. Improving drought tolerance is vital to improve the performance and stability of the yield, but efficient selection protocols and the mixed breeding system of this crop pose major challenges for effective plant breeding programs $[17,18]$. Field phenotyping for drought responses is expensive and time-consuming and is often unrepeatable because of variations in the timing of onset, duration and severity of the drought [19]. The mean outcrossing rate is about $33 \%$, depending on the population of pollinators, cultivars and environmental conditions [20], and if cross-pollination between susceptible and tolerant plants occurs before drought stress occurs, the effectiveness of selection for the drought response is compromised [21]. On the other hand, controlled condition screening based on secondary physiological characteristics of roots and shoots, including stomatal conductance, relative water content, water potential, osmotic potential, root morphology, root plasticity and isotopic carbon discrimination, can provide generally reliable and repeatable information for selection, but the population size is compromised. Metabolic profiling, which provides insight into how changes in metabolite concentrations are influenced by changes in the environment, also holds great promise. In this review, we bring together the current physiological and biochemical knowledge on traits related to drought adaptation in the faba bean and elaborate how this knowledge can be used in breeding faba beans. A schematic overview of the roadmap to achieving these aims and how these relate to one another is shown in Figure 2. 


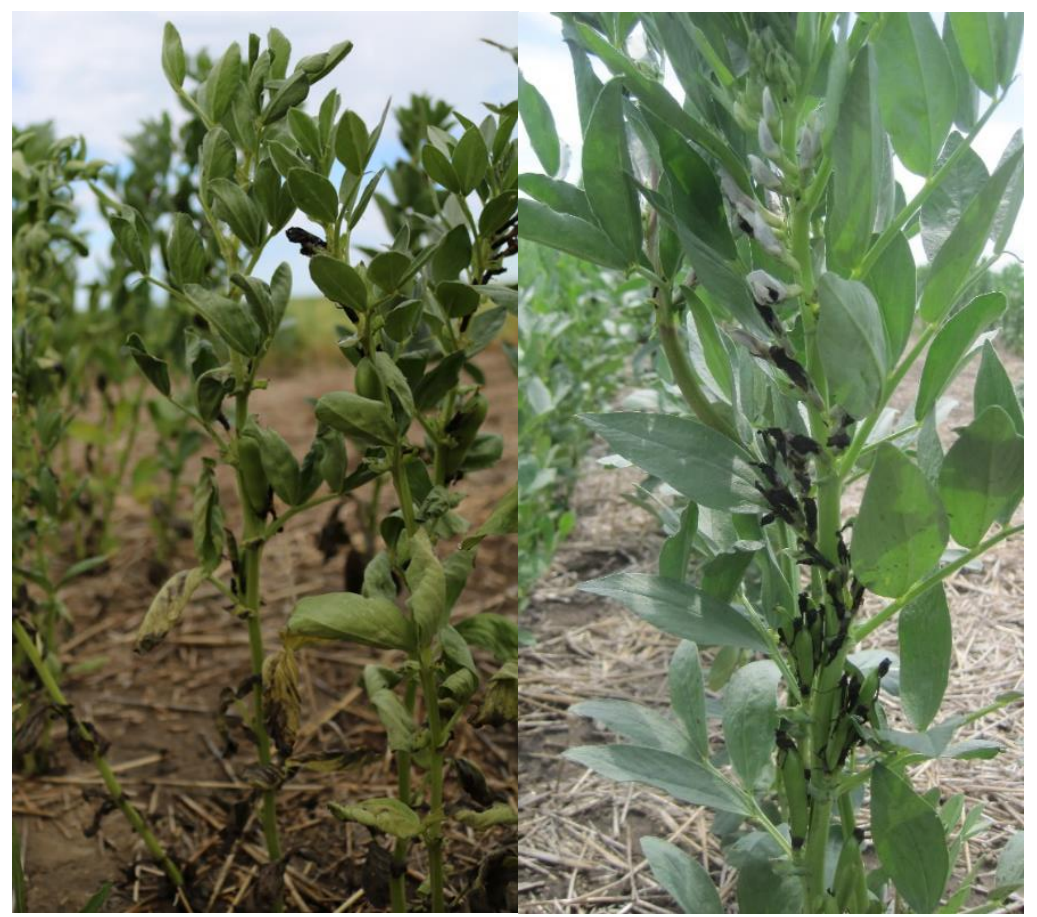

Figure 1. Faba bean plants (FB 9-4) under water-deficit conditions (left) and irrigated conditions (right) in Limerick and Outlook, Saskatchewan (Canada), respectively.

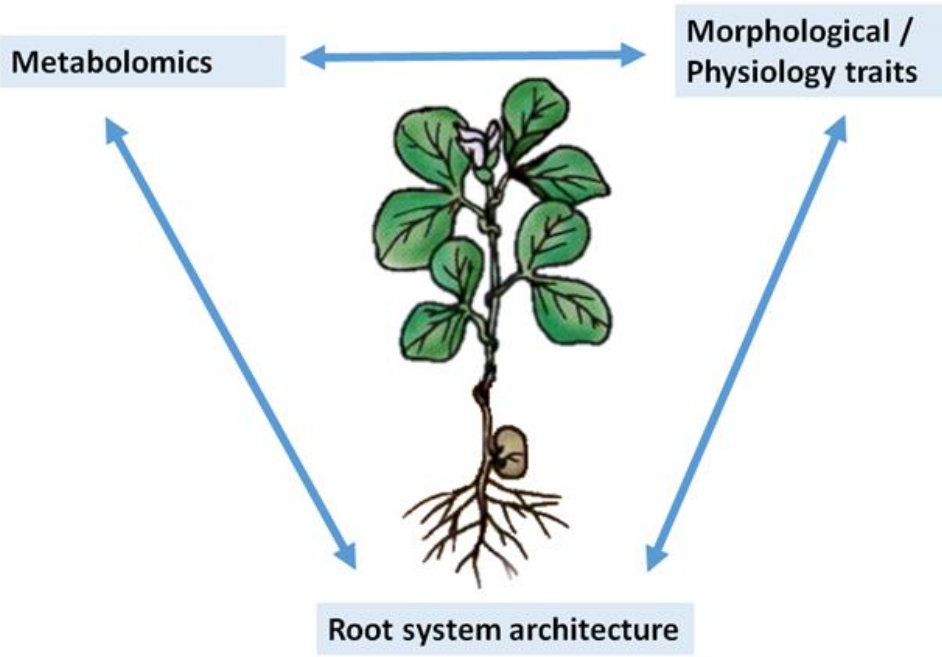

Figure 2. The key elements of the roadmap and how these relate to one another.

\subsection{Faba Bean Yield Response to Drought}

Three types of strategies to cope with drought stress have been characterised-namely, drought avoidance, drought dehydration tolerance and drought escape. Drought avoidance refers to mechanisms related to keeping a high plant water status under water-limited conditions by minimising the water loss and maximising the water uptake through root characteristics. Dehydration tolerance refers to maintaining metabolic activities at the low-tissue water potential (surviving internal water deficits). Drought escape is the ability of a crop to complete its life cycle before the onset of drought or unfavourable conditions [22]. The faba bean is prone to water deficit from seedling to maturity [19,22], but in the Mediterranean-type climates, where it is sown in autumn and harvested in spring as the temperature increases and rainfall declines, the faba bean often experiences so-called "terminal" droughts [23]. Adapted materials escape terminal droughts by early maturity, completing their life 
cycles before a drought occurs, often accompanied by a yield penalty. Besides terminal drought, the faba bean often experiences transient droughts in subtropical and temperate environments. Transient droughts reduce the plant stature and number of reproductive nodes in faba beans [24]. In contrast to escaping, there is no comparable and simple strategy to deal with unpredictable and intermittent transient droughts. Maintaining higher relative water contents under water deficits, which demonstrates effective stomatal regulation and stomatal function [25], root morphology, plasticity and function [26], epicuticular wax and osmotic adjustment [22], play vital roles in the management of transient droughts.

Although the faba bean originates from a semi-arid region, drought adaptation is not common. Its relatively shallow root system $[27,28]$ is unable to extract water from deep soil, causing moisture stress during the reproductive phase when the topsoil dries. Genetic resources that can adjust to variations in soil moisture levels exist [19,29-33], indicating that there is potential to breed for moisture-limited environments. Link et al. [32] selected drought-tolerant cultivars and breeding lines from the Mediterranean region where water distribution is irregular and moisture levels are moderate ( $500 \mathrm{~mm}$ rainfall). Maalouf et al. [34] also found different tolerance levels to water deficits. The existence of wide genotypic variations makes it possible to develop drought-tolerant faba bean genotypes through classical breeding approaches.

The plant developmental stage and the magnitude of water deficit determine the yield loss of the faba bean. The most susceptible stages for developmental inhibition have been variously described as flowering [35], early podding [36] and pod setting [37], but all of these studies generally agree that the early reproductive phase is the most sensitive stage [19,38]. Moderate drought stress had a negative effect on the pod number per plant but had no effect on the seed size or seed number per pod [35,39]. The extent of drought stress determined whether the plant had partial damage or complete death. These observations highlight the importance of identifying the developmental stage when assessing the impact of drought conditions in faba beans.

Seed quality is also affected by water deficit. Genotypic background and environmental factors, i.e., drought and heat, are the major factors that regulate seed protein contents [40]. Winter faba beans have slightly higher protein concentrations than spring beans, which may be interpreted as an indication that water deficits tend to increase protein contents [41]. Faba bean crops grown in water-deficit conditions have improved proteins [42] and sulphur contents [43] compared to those grown with adequate water. In drought-prone environments, reduced protein biosynthesis is due to reducing the $\mathrm{N}$ fixation and partitioning [44]. On the other hand, Smith [45] reported that droughts caused yield reductions but did not alter the mineral nutritional quality (calcium, iron, potassium, magnesium, phosphorus, sulphur and zinc) or amino acid concentrations in the common bean. Generally, seed mineral uptake is not impacted by drought. A high $\mathrm{N}$ fixation is usually observed in the faba bean under optimal conditions, whereas droughts can considerably impair the $\mathrm{N}$ fixation $[46,47]$. Under water deficits, modifications of the bacteroid environment cause the decline in $\mathrm{N}$ fixation [48] and reduced nodule numbers in faba beans [49].

Combined, these observations illustrate the importance of physiological responses to droughts in the faba bean and the influence this has on crop yields and yield quality. It is therefore important to identify tools by which the physiological status may be quantified to assist in management and breeding to help mitigate the effects of drought conditions on plant performances.

\subsection{Physiological Attributes Related to Stress Adaptation}

It is well-established that the phenotypic selection, based on adaptive traits that are secondary to yield, can be used for improving production in water-limited environments [50-52]. Secondary traits chosen for this purpose should be genetically associated with yield in the target environment, highly heritable and easy to measure. Drought-tolerance trait selections were found to be more meaningful when conducted on a large population [53]. Several physiological traits, including water use efficiency (WUE) [31], stomatal features [54-56], leaf temperature and carbon isotope discrimination [19], have 
been found to be suitable selection criterion for the improvement of drought adaptation in faba bean breeding programs.

Drought stress interacts with low temperatures, soil salinity and $\mathrm{Al}^{3+}$ toxicity. Salinity and drought affect the osmotic equilibrium in a similar way [57], while $\mathrm{Al}^{3+}$ toxicity hampers root development [58], and cold affects both the movement of water within roots and the ability of the plant to develop symbiosis [59]. Among legumes, Al-drought interactions have been studied in the common bean [60] and soybean (Glycine max (L.) Merr.) [61], and the $\mathrm{Al}^{3+}$ toxicity exacerbated the effects of the drought mainly due to its inhibition of root growth. On the other hand, the drought was reported to ameliorate $\mathrm{Al}^{3+}$ injury by reducing the uptake of the toxic ion. The Al-drought interaction has a synergistic effect on crops, rendering them unable to recover after exposure to these stresses. Salinity coupled with drought reduced the symbiotic nitrogen fixation, which may be due to its effect on the supply of photosynthates or oxygen to the nodule and bacteroids [62]. Crosstalk in stress signalling and gene expression has been reviewed in drought and cold stress responses [63] and in cold and salinity responses [57]. In the faba bean, little genetic connection between the drought response and freezing tolerance was observed [64].

\section{Root Traits}

Compared with the aboveground traits, relatively few studies have been performed on belowground traits. A root trait analysis is complex, involving clumsy measurement systems, so maintaining a high level of precision is difficult in field level screening [65]. Among the root architectural features, morphology and plasticity are the two general types of variation that exist. Genetic variations in root morphological characteristics have a significant influence on the capacity and efficacy of a plant to search for and absorb moisture and nutrients from the soil. Deep-rooted soybean genotypes have a higher water-absorption capacity from deep horizons of soil, leading to a higher yield potential [66]. Moreover, the alteration of the root architecture (plasticity) follows several mechanisms under stress and nutrient availability. For example, the root/shoot biomass ratio increased in white lupin (Lupinus albus L.) and Andean lupin (L. mutabilis Sweet) during water deficit [67]. Changes in the root density of L. angustifolius genotypes in response to phosphorus availability have also been observed [68]. Faba bean genotypes with extensive and prolific root characteristics usually exhibit drought tolerance [29]. A variability in the root characteristics and root-based phenotyping for drought tolerance was also found in cowpeas [69], chickpeas [65,70,71], lentils [72,73] and the common bean [74].

Under water-deficit conditions, Husain et al. [75] showed an increased root growth per unit area during the flowering stage. Manschadi et al. [27] described the root length density, along with the dry root weight, and both were considerably reduced under drought conditions. Belachew et al. [26] identified root phenotypic markers associated with drought avoidance characteristics in young faba bean plants in GROWSCREEN-Rhizo boxes, a phenotyping robotic tool for measuring root and shoot growths [76]. Accordingly, two faba bean accessions (IG 70622 and IG 11320) that exhibit deeper root systems and higher root area coverage, displayed drought-avoidance traits through the maintenance of their primary and tertiary root lengths relatively well. The same observation was noted by Muktadir et al. [77] while screening drought-adapted genotypes in a hydroponic screening system. The growth of the tap root in the faba bean is a major influence on the total rooting depth; however, the tap root appears unable to acquire water for growth, even if the root surface has access to it. At shallow depths, lateral root growth is important for access to surface moisture and nutrients and is thought to be a major influence on plant health. Selection on the basis of rapid growth of the taproot and expansion of the lateral root system to maintain the root length density and dry root weight may be an effective method for increasing drought adaptation in faba bean breeding programs. There has been limited research on the genetic variability of root growth and branching in faba beans. Appropriate measurements of root systems include root mass, root mass fraction, rooting volume, root length and 
root/shoot ratio. Among them, the root mass is probably the easiest to measure, as, in chickpeas, it was strongly correlated to the shoot mass and represented $30-34 \%$ of the total dry matter [65].

\section{Shoot Related Traits}

Under stress conditions, selection for a higher yield is not always effective, because yield is controlled by several traits controlled by quantitative trait loci (QTL). To select genotypes for drought tolerance, the breeding process should be focused on the contributing characteristics rather than the yield itself. Contributing characters need to be causal, and shoot-related traits play a vital role in maintaining the water status when grown in water-deficit conditions.

\subsection{Leaf/Canopy Temperature}

The temperature of the exterior of the canopy is related to the vapour pressure deficit and directly influences the amount of transpiration that leads to cooling by evaporation. Direct and easy measurement of the canopy temperature (CT) without disturbing the crop can be completed by using an infrared thermometer (IRT), which can be mounted on a drone to cover a large area in a relatively short time to minimise environmental fluctuations. Blum et al. [78] introduced CT as a selection trait for dehydration tolerance. During water-deficit conditions, closed stomata cause a decrease in transpiration, which ultimately leads to an increase in leaf temperature $[79,80]$. In field conditions, maintaining a lower $\mathrm{CT}$ is generally linked with improving the absorption capacity of a plant under stress conditions [81]. CT can be used as a substitute selection trait to screen faba bean genotypes grown in control environments $[19,22]$. In a large set of faba bean germplasm collected from regions with contrasting moisture regimes around the globe, the leaflet and canopy temperatures were the most informative measurements distinguishing the germplasm from wet and dry origins $[82,83]$. CT has been found to be a prominent trait associated with drought tolerance for soybeans [84], chickpeas [85-87], cowpeas [88] and lentils [89]. The preference for use of CT is its noninvasive nature and application to early evaluations in large numbers of genotypes. The protocol for using an IRT should be followed carefully to avoid a large variance error and nonrepeatable results. Thermal infrared imaging of crop canopies is a further technology for the study of stomatal responses and for phenotyping plants for differences in stomatal behaviours. The use of remote imaging, when combined with an effective image analysis tool, provides a powerful approach for the comparison of large germplasm collections in typical field conditions [90].

\subsection{Leaf Water Relations}

During water-deficit conditions, plants may maintain the water potential by the production and accumulation of cellular metabolites/osmotica, which are sensed by stomata for the maintenance of sustaining the turgor pressure. Plant species and their developmental stages are the determinants of the types and functions of these metabolites. Relatively few candidate molecules can function as cellular osmotica, as they must be compatible with cellular functions at high concentrations. These candidate molecules may be organic acids, inorganic ions, polyols, polyamines and carbohydrates. In chickpeas, carbohydrates and polyols contribute more than $50 \%$ to the osmotic pool [23], and in field peas, these ranged from 10-46\% [91]. More broadly, the osmotic potential ( $\psi \mathrm{s})$ and turgor potential $(\psi p)$, the two main components of leaf water potential $(\psi)$, were found to be an effective selection trait for drought tolerance screening. Generally, leaf $\psi$ is considered a major component of the leaf-level water deficit [92], and it can ultimately drive interpretations of the plant water status [93,94]. Sustaining leaf $\psi$ under stress involves a number of mechanisms that are related to both root and shoot and are considered to be connected to drought avoidance [95]. Higher leaf turgor in response to water deficit is one of the adaptation strategies for many plant species $[96,97]$. Osmotic adjustment-driven drought adaptation was also observed in chickpeas [98,99], field peas [100] and lentils [101,102]. In faba beans, drought tolerance through osmotic adjustment has not yet been demonstrated in the wide germplasm but, as a selection criterion under drought, is sporadically observed, e.g., [103]. Metabolic adjustments 
in response to drought conditions may highlight pools of metabolites that play vital roles in the metabolism and physiology and may indicate which pathways have been perturbed by the stress.

\subsection{Relative Water Content}

The relative water content (RWC) is a robust and simply assessable selection criterion that can describe the plant water status to the metabolism irrespective of plant parts and species. It can be expressed as the water content of tissues in normal conditions compared to hydrated conditions [104]. During water-deficit conditions, the RWC plays an important role by preserving water (stomatal features, leaf area reduction and leaves dropping) or maximising the water absorption (root plasticity). Sinclair and Ludlow [105] found the RWC superior over water potential to assess plant water statuses. Khazaei et al. [55] stated the RWC as one of the most important traits that differed between wet- and dry-adapted faba bean accessions under nonstress conditions. The RWC is composed of a relative change in cell turgor and $\psi$ s, so it relates to both the solute concentrations and cell wall rigidity [106]. The RWC can efficiently identify drought-tolerant genotypes based on their plant water status in faba beans $[19,82,107]$, common beans [108] and chickpeas $[109,110]$. Therefore, it can be said that genotypes that can sustain a higher RWC in a water deficit environment would be suitable for use in breeding faba beans for drought adaptation.

\subsection{Stomatal Conductance}

Drought avoidance involves the maintenance of gas exchange during drought conditions, which causes either higher stomatal conductance, $\mathrm{g}_{\mathrm{s}}$ (low stomatal sensitivity to drought) or stomatal closure to restrict water loss. There is a trade-off between gas exchange and stomatal closure during stress, which ultimately affects photosynthesis and, then, carbon assimilation. Stomatal conductance has been proposed as an effective selection tool and, when measured on multiple plants in a canopy, is equally effective as CT [111]. The measurement of $g_{s}$ depends on several stomatal features. Faba bean stomatal characteristics are assessed through microscopy [25,29], but due to the rapid response to stress, the stomatal opening size is hard to measure. Leaf porometer or portable photosynthesis machines quantify $g_{s}$ but may not reflect the variability over longer timeframes, as it changes rapidly. The measurement of $g_{s}$ is highly influenced by environmental conditions (high genotype by environment interaction), time of day and plant developmental stage. Leport et al. [101] found that white lupin, chickpeas, faba beans, field peas, grass peas (Lathyrus sativus L.) and lentils all responded similarly under water-deficit conditions. During early stage drought, $\mathrm{g}_{\mathrm{s}}$ was remarkably reduced, but at later stages, after the initiation of pod filling, it had little or no effect. Faba bean genotypes with higher stomatal density were lower-yielding and exhibited low drought tolerance, while genotypes with low stomatal density performed better in stress conditions [56]. In a relatively small set of faba bean germplasm, $g_{s}$ was found to be an important vital trait $[19,112]$. The considerable variation for $\mathrm{g}_{\mathrm{s}}$ among 402 faba bean accessions under nonstress conditions indicates the potential use of this trait [25]. The drought treatment of faba beans during the first three weeks of growth resulted in the expected reductions in biomass and $g_{s}$ [113]. The gas exchange measurements, along with stomatal morphology characteristics, have been genetically mapped in the faba bean. The QTL governing stomatal morphology, $\mathrm{g}_{\mathrm{s}}$ and CT were all co-located in faba bean chromosome 2 [83]. A study of the gene actions showed that breeders selecting for the productivity of faba beans can maximise genetic gain by selecting early generations for $\mathrm{CT}$ and $\mathrm{g}_{\mathrm{s}}[114]$.

The effectiveness of stomatal control over transpiration efficiency increases if nonstomatal transpiration pathways are restricted. An important nonstomatal water vapour pathway is the leaf cuticle. The epicuticular wax (ECW) quantity is considered as an important drought avoidance strategy in plant species. There was a considerable variation for ECW in 197 faba bean accessions, ranging from 0.680 to $2.104 \mathrm{mg} / \mathrm{dm}^{2}$ [115]. This variation may allow the genetic improvement of ECW as a drought-adaptive character in faba bean breeding programs. 


\subsection{Carbon Isotope Discrimination}

Carbon isotope discrimination $(\Delta)$ is proposed extensively as a proxy for the plant physiological status, especially WUE [116]. It is used to evaluate the transpiration efficiency (TE) in cereals and, more recently, in legumes, common beans [117-119], soybeans [120], chickpeas [121], cowpeas [122] and lentils [123]. In faba beans, drought-tolerant genotypes ILB 938 and Mélodie had significantly lower $\Delta$ than those of the drought-susceptible genotypes, e.g., Aurora [19]. In a larger faba bean germplasm, $\Delta$ varied from $24.43 \%$ to $28.82 \%$, equivalent to an intrinsic water use efficiency (WUE $\mathrm{W}_{\mathrm{i}}$ ) of 98.53-179.75 $\mu \mathrm{mol} \mathrm{CO} \mathrm{Col}^{-1} \mathrm{H}_{2} \mathrm{O}$ (manuscript in preparation). There is some controversy regarding the relationship between $\Delta$ and TE. Turner et al. [123] argued that TE was not significantly correlated with $\Delta$ in three grain legumes, i.e., lentils, narrow-leafed lupin (L. angustifolius L.) and chickpeas. Carbon isotope discrimination may not always indicate the prediction of actual WUE, because generally, $\Delta$ is measured from leaf tissue, which has limitations for estimating short-term environmental changes [124]. Carbon isotope discrimination-based screening methods are expensive and require sophisticated and costly instrumentation, e.g., isotope ratio mass spectrometry (IRMS). A wider spectrum of faba bean germplasm needs to be surveyed for genetic variations in $\Delta$ under various environmental conditions to allow $\Delta$ to be used as a strong screening tool in faba breeding programs.

\section{Metabolomics for Legume Breeding}

Metabolomics is a fast-emerging area of knowledge that integrates gene expression, protein interaction and other regulatory progressions. Nowadays, metabolic products are used as biomarkers in crop improvement due to their strong linkage with environmental characteristics [125]. So far, more than 200,000 metabolites have been identified in plants. These have a diverse set of functions and quantification, and the qualification of these composite characteristics into subsets of metabolic functions can offer a unique view of the inducible chemical and physiological response mechanisms [126]. The identification and quantification of low molecular weight metabolites require special analytical and separation techniques involving gas chromatography (GC) [127], liquid chromatography (LC) [127,128] and high-performance liquid chromatography (HPLC) [129]. These methods can characterise a vast range of metabolites at extraordinary scales and accuracy. Recently, nuclear magnetic resonance (NMR) has provided a greater ability for researchers to profile metabolites [130].

Metabolic profiling studies of grain legumes are relatively unexplored and seemingly absent for faba beans. Zhang et al. [131] studied metabolic variations between symbionts in Medicago truncatula Gaertn. through an untargeted quantitative mass spectrometry-based (MS) method. Short-term water deficit effects on the overall growth through metabolic changes were studied by NMR-based metabolic profiling [132]. Plants produce many primary and secondary metabolites during stress. Two different options can define this process: osmotic adjustment, where the plant regulates solute synthesis to decrease the osmotic potential under adverse situations [133], and solute accumulation, which occurs due to reductions, interruptions or fluctuations in the solute transport [134]. Generally, osmotica are easily synthesised from readily accessible antecedents and are transformed to metabolically active and movable compounds. Overall, pre-existing metabolomic resources for legume research will benefit faba bean improvements. However, accelerated applications of these tools may uncover new solutes/biochemical markers for stress tolerance in faba bean breeding.

\subsection{Metabolite Accumulation in Legumes in Response to Drought and Their Use as Biomarkers}

\subsubsection{Amino Acids}

The accumulation of amino acids and other nitrogen-based molecules in response to stress is one of the most important biochemical signals for almost all plants. These essential metabolites are shown to accumulate during stresses in different legumes, including the model species M. truncatula and soybeans [135-139]. The accumulated enhanced protein breakdown is triggered by stress, and a higher amino acid concentration helps a plant to survive under stress [140]. 
Proline is found to be the most prevalent amino acid found in plant tissues under stress conditions (drought, cold and salinity). Singh et al. [141] demonstrated a correlation between drought and an increased free proline accumulation in drought-tolerant barley cultivars compared to a more drought-susceptible genotype. Similar correlations have been found in other crops [142], but there are also reports of poor correlations between drought and proline accumulations [143] in legume species. For example, Lotus spp. and soybeans showed a positive association with increased proline concentrations during the reproductive stage only [132,144]. Again, during water deficit, proline accumulation was observed in the pre-flowering stage of peanuts (Arachis hypogaea L.) [145]. Proline accumulation relies not only on the water status but, also, on the growth stage of the plant. Short-term stress can be identified through proline quantification. Venekamp et al. [146] found that just one day of water deficit at the seedling stage induced proline accumulation. An increased proline concentration in faba beans was observed with the increase of the stress intensity, and the variation in proline concentrations at the genotypic level was reported to be low under optimal conditions $[46,107,147,148]$. However, an exogenous proline application can decrease stomatal opening under drought, and this had a positive impact on drought tolerance mechanisms $[149,150]$. Proline accumulation provides an indication of the plant physiological status, i.e., whether it is stressed or not, but not a descriptive drought tolerance indicator in faba beans. An exogenous application of $\beta$-aminobutyric acid (BABA) as a nonprotein amino acid was shown to enhance the accumulation of proline and soluble sugars, which improved drought adaptation in faba beans [151].

Besides proline accumulation, other amino acids are also observed in response to droughts in plants [152]. In lentils, methionine, isoleucine, valine, arginine and histidine increased under drought stress [138]. Drought stress-mediated GABA (gamma-aminobutyric acid) synthesis was observed in Arabidopsis thaliana, soybeans and common beans [153]. Abiotic stresses enhanced cytosolic $\mathrm{Ca}^{2+}$ levels, which ultimately promoted GABA synthesis, but until now, no evidence was found where GABA stimulated the stomata opening or closing through its ion transporter function [154].

\subsubsection{Polyamines}

Another plant response to abiotic stresses is polyamines (PA) synthesis, but the association between PA accumulation and fortification remains inconclusive. Three commonly found polyamines are putrescine, spermidine and spermine. Usually, stress-tolerant accessions contain a higher amount of PA than sensitive accessions $[155,156]$. Nevertheless, all three PAs do not accumulate at the same time, but one type of PA shows a stronger response. For example, under PEG-osmotic stress conditions, lentil cotyledons and roots exhibited increased putrescine and spermidine, while the cadaverine presence was nonsignificant. Drought-adapted yellow lupin (L. luteus L.) accessions produced a high amount of PAs compared to moderately adapted genotypes. Drought stress also increased the concentrations of spermidine and spermine [156]. Beside leaves, seeds commonly exhibit opposite trends, where leaves accumulate more Pas, and the seed content is reduced. Nayyar et al. [157] observed more PA accumulations in chickpeas compared to soybeans under water-deficit conditions. In relay cropping with legumes, 18 rice (Oryza sativa L.) cultivars showed significantly higher spermine levels when exposed under salt stress [158]. With this information, it can be said that PA accumulation does not depend on a single factor. Multiple factors like plant species, stress type and level, and the physiological status of the studied tissues, are involved. The PA dynamics of abiotic stress effects can unveil contradictory results of PA accumulation. The stress tolerance of a given species often correlates with the PA pool size, which can answer some underlying questions about the importance of PAs in assisting the protection against stresses. In faba beans, spermine, cadaverine and total polyamine increased in parallel with the salinity level, whereas the putrescine and spermidine levels decreased [159]. In faba beans, PA accumulations in response to drought stress have not been studied to date. 


\subsubsection{Organic Acids}

Organic acid plays an important role in plant metabolism as an early source of photosynthesis and precursors of the synthesis of many other compounds. Organic acids support stomata regulation, ion equilibrium, ammonium manufacture and nutrient absorption [160]. Among the profiled metabolite classes estimated from soybean leaf tissue, organic acids occupy around 20\% of the metabolites [161]. Nitrogen fixation in the nodule is impacted by the malic acid concentration, which regulates the bacteroid respiration [162]. The abundance of organic acids also depends on the type of organ. Organic acid concentrations were lower in lentil root tissue than in cotyledon tissue [138]. Sassi et al. [163] observed a reduced amount of organic acids in common bean leaves under osmotic stress conditions. The amount of succinate was doubled in drought-treated soybean leaves. In lentils, isocitric, nicotinic and oxaloacetic acid concentrations increased considerably in plants exposed to osmotic stress [164]. In soybeans, reduced amounts of organic acids in drought-adapted genotypes suggested metabolic flexibility, as plants shifted from growth to survival [132]. Organic acid functions in response to stress in faba beans have not yet been demonstrated, but it could become an area for future enquiry.

\subsubsection{Carbohydrates}

Carbohydrates are often referred to as appropriate osmotica and represent one of the main components of osmoregulation in many plant species [165]. The metabolic profiling of the model forage legume Lotus japonicus L. when affected by drought showed the accumulation of the sugars fructose, galactose, glucose and maltose, while arabitol, ununitol and galactitol were the most abundant polyols [144]. In soybean leaves, about $30 \%$ of the metabolites identified were soluble sugars and sugar alcohols, which are important for plant adaptation against stresses, especially during water deficits [161]. The close association among carbohydrates and their involvement in the primary metabolism suggested a molecular modification may be possible to improve the stress tolerance through the synthesis and degradation of these compounds [166]. However, there is no general acceptance of the hypothesis that "osmotic adjustment arises from the accumulation of solute due to the persistence of photosynthesis after cessation of leaf growth" [133].

Among the dominant carbohydrates, trehalose, a nonreducing disaccharide, accumulates in large quantities in the unusual desiccation-tolerant plant Myrothamnus flabellifolia Wolw. [167,168]. High levels of trehalose can stabilise proteins and membranes [169]. It has been recently reported that rhizobium inoculation can also increase the dehydration tolerance of several legume species through trehalose biosynthesis [170-173]. Moreover, an increased trehalose concentration was found to be a significant contributor to drought tolerance [174]. Polyhydric alcohols or polyols are a major metabolite group reviewed by Merchant and Richter [175]. The quantity of polyols found in plant tissues was found to be sensitive to environmental conditions [176,177]. Further, Dumschott et al. [178] characterised D-pinitol as being influenced by the developmental stage. D-Pinitol is present in most legumes at some level under optimal conditions, but an increase is triggered during water and salinity stress [179]. While there is a general consensus on the function of pinitol in plant systems, gaps remain in understanding the conditions leading to pinitol accumulation, as well as the molecular control of the accumulation.

\section{Faba Bean Genetic Resource to Aid Breeding for Drought Adaption}

A wealth of faba germplasm is available, comprising over 43,000 accessions (Dr. Kenneth Street, personal communication) that are conserved mostly within 37 global gene banks. The ICARDA (International Centre for Agricultural Research in the Dry Areas) collection exceeds 9000 accessions ( $21 \%$ of the global collection) [55]. Wide genetic variations have already been reported in faba bean genetic resources for various traits, including physiological traits related to drought adaptation (reviewed in [82]). This enormous variability is expected in this ancient domesticated crop with its wide adaptability to various latitudes and altitudes. The rich germplasm collection of faba beans 
should be systematically maintained and could be characterised for the physiological and metabolic parameters in order to improve drought adaptation in this species.

\section{Conclusions}

Improvement of global faba bean production will have a positive impact on the food supply and cropping systems of many nations. Tools to improve faba bean production will incorporate both management activities and improved genotypes. The adoption of these tools must balance the necessity for broad-scale characterisations and cost with the precision required for appropriate detection at the plant scale. Many traits have been identified for drought tolerance studies. Some traits, like canopy temperature, can be used efficiently for large numbers of genotypes in breeding programs, while, for example, carbon isotope discrimination is largely limited to low numbers of genotypes. Metabolite-based biomarkers and bioindicators can easily supplement the selection process in faba bean breeding programs. The identification and quantification of given primary and/or secondary metabolites against specific stresses could become valuable decision-making tools for plant breeders if their associations are of sufficient strength and their analytical costs are low. The available metabolomic resources from other legumes should be explored to understand the molecular insights of stresses. The large genome of the faba bean is currently being sequenced, which will soon make molecular breeding possible. Finally, no single trait and approach are adequate to improve yields under drought conditions, the most complex environmental factor for faba bean productivity. A combination of screening methods suitable for specific environments and expansion of the scale of breeding will be required to allow expansion of the production area and yield of the faba bean, a crop that is an increasingly important source of plant-based protein in drought-prone production regions.

Author Contributions: Writing—original draft preparation, M.A.M., and writing-review and editing, K.N.A., A.M., K.Y.B., A.V., F.L.S. and H.K. All authors have contributed, read and agreed to the published version of the manuscript.

Funding: M.A.M. acknowledges the support from University of Sydney International Scholarship and also supplemented by the Grains Research and Development Corporation. K.Y.B.'s participation was funded by the European Union through its ERANET SusCrop projects "ProFaba" and "LegumeGap". H.K. acknowledges funding from Agriculture Development Fund (Government of Saskatchewan, Canada); Western Grains Research Foundation, Canada; Saskatchewan Pulse Growers, Canada; and the NORFAB (Protein for the Northern Hemisphere) project funded by Innovation Fund, Denmark.

Acknowledgments: M.A.M. sincerely acknowledges the contributions of Abdus Sadeque at the Plant Breeding Institute, Narrabri, The University of Sydney for his valuable suggestions and direction during early draft preparation.

Conflicts of Interest: The authors declare no conflict of interest.

\section{References}

1. Food and Agriculture Organization of the United Nations. FAOSTAT. Available online: http://faostat.fao.org (accessed on 21 July 2020).

2. Caracuta, V.; Barzilai, O.; Khalaily, H.; Milevski, I.; Paz, Y.; Vardi, J.; Regev, L.; Boaretto, E. The onset of faba bean farming in the Southern Levant. Sci. Rep. 2015, 5, 14370. [CrossRef]

3. Lawes, D.; Bond, D.; Poulsen, M. Classification, origin, breeding methods and objectives. In The Faba Bean (Vicia faba L.); Hebblethwaite, P.D., Ed.; Butterworths: London, UK, 1983; pp. 23-76.

4. Emshwiller, E.; Calberto-Sánchez, G.; Girma, G.; Jansky, S.; Sardos, J.; Staver, C.; Stoddard, F.L.; Roux, N. Unavailability of wild relatives. In Crop Wild Relatives and Climate Change; Redden, R., Yadav, S.S., Maxted, N., Dulloo, M.E., Guarino, L., Smith, P., Eds.; John Wiley \& Sons: Oxford, UK, 2015; pp. 222-258.

5. Caracuta, V.; Weinstein-Evron, M.; Kaufman, D.; Yeshurun, R.; Silvent, J.; Boaretto, E. 14,000-year-old seeds indicate the Levantine origin of the lost progenitor of faba bean. Sci. Rep. 2016, 6, 37399. [CrossRef]

6. Watson, C.A.; Reckling, M.; Preissel, S.; Bachinger, J.; Bergkvist, G.; Kuhlman, T.; Lindström, K.; Nemecek, T.; Topp, C.F.E.; Vanhatalo, A.; et al. Grain legume production and use in European agricultural systems. Adv. Agron. 2017, 144, 235-303. 
7. Hauggaard-Nielsen, H.; Mundus, S.; Jensen, E.S. Nitrogen dynamics following grain legumes and subsequent catch crops and the effects on succeeding cereal crops. Nutr. Cycl. Agroecosyst. 2009, 84, 281-291. [CrossRef]

8. Hoffmann, D.; Jiang, Q.; Men, A.; Kinkema, M.; Gresshoff, P.M. Nodulation deficiency caused by fast neutron mutagenesis of the model legume Lotus japonicus. J. Plant Physiol. 2007, 164, 460-469. [CrossRef] [PubMed]

9. Horst, I.; Welham, T.; Kelly, S.; Kaneko, T.; Sato, S.; Tabata, S.; Parniske, M.; Wang, T.L. TILLING mutants of Lotus japonicus reveal that nitrogen assimilation and fixation can occur in the absence of nodule-enhanced sucrose synthase. Plant Physiol. 2007, 144, 806-820. [CrossRef] [PubMed]

10. Baddeley, J.; Pappa, V.; Pristeri, A.; Bergkvist, G.; Monti, M.; Reckling, M.; Schläfke, N.; Watson, C. Legume-based green manure crops. In Legumes in Cropping Systems; Murphy-Bokern, D., Stoddard, F.L., Watson, C.A., Eds.; CAB International: Oxford, UK, 2017; pp. 125-138.

11. Duc, G. Faba bean (Vicia faba L.). Field Crops Res. 1997, 53, 99-109. [CrossRef]

12. Khazaei, H.; Vandenberg, A. Seed mineral composition and protein content of faba beans (Vicia faba L.) with contrasting tannin contents. Agronomy 2020, 10, 511. [CrossRef]

13. Feedipedia. Faba bean (Vicia faba). 2018. Available online: https://www.feedipedia.org/node/4926 (accessed on 21 July 2020).

14. Crépon, K.; Marget, P.; Peyronnet, C.; Carrouee, B.; Arese, P.; Duc, G. Nutritional value of faba bean (Vicia faba L.) seeds for feed and food. Field Crops Res. 2010, 115, 329-339. [CrossRef]

15. Oweis, T.; Hachum, A.; Pala, M. Faba bean productivity under rainfed and supplemental irrigation in northern Syria. Agric. Water Manag. 2005, 73, 57-72. [CrossRef]

16. Daryanto, S.; Wang, L.; Jacinthe, P.A. Global synthesis of drought effects on food legume production. PLoS ONE 2015, 10, e0127401. [CrossRef] [PubMed]

17. Drayner, J.M. Regulation of outbreeding in field beans (Vicia faba). Nature 1956, 177, 489-490. [CrossRef]

18. Stoddard, F.L.; Balko, C.; Erskine, W.; Khan, H.R.; Link, W.; Sarker, A. Screening techniques and sources of resistance to abiotic stresses in cool-season food legumes. Euphytica 2006, 147, 167-186. [CrossRef]

19. Khan, H.R.; Link, W.; Hocking, T.J.; Stoddard, F.L. Evaluation of physiological traits for improving drought tolerance in faba bean (Vicia faba L.). Plant Soil 2007, 292, 205-217. [CrossRef]

20. Stoddard, F.L.; Bond, D.A. The pollination requirements of the faba bean. Bee World 1987, 68, $144-152$. [CrossRef]

21. Palmer, R.G.; Perez, P.T.; Ortiz-Perez, E.; Maalouf, F.; Suso, M.J. The role of crop-pollinator relationships in breeding for pollinator-friendly legumes: From a breeding perspective. Euphytica 2009, 170, 35-52. [CrossRef]

22. Khan, H.R.; Paull, J.G.; Siddique, K.H.M.; Stoddard, F.L. Faba bean breeding for drought-affected environments: A physiological and agronomic perspective. Field Crops Res. 2010, 115, 279-286. [CrossRef]

23. Amede, T.; Schubert, S. Mechanisms of drought resistance in grain legumes I: Osmotic adjustment. Ethiop. J. Sci. 2003, 26, 37-46. [CrossRef]

24. Gnanasambandam, A.; Paull, J.; Torres, A.; Kaur, S.; Leonforte, T.; Li, H.; Zong, X.; Yang, T.; Materne, M. Impact of molecular technologies on faba bean (Vicia faba L.) breeding strategies. Agronomy 2012, 2, 132-166. [CrossRef]

25. Khazaei, H.; Street, K.; Santanen, A.; Bari, A.; Stoddard, F.L. Do faba bean (Vicia faba L.) accessions from environments with contrasting seasonal moisture availabilities differ in stomatal characteristics and related traits? Genet. Resour. Crop Evol. 2013, 60, 2343-2357. [CrossRef]

26. Belachew, K.Y.; Nagel, K.A.; Fiorani, F.; Stoddard, F.L. Diversity in root growth responses to moisture deficit in young faba bean (Vicia faba L.) plants. PeerJ 2018, 6, e4401. [CrossRef]

27. Manschadi, A.M.; Sauerborn, J.; Stützel, H.; Göbel, W.; Saxena, M.C. Simulation of faba bean (Vicia faba L.) root system development under Mediterranean conditions. Eur. J. Agron. 1998, 9, 259-272. [CrossRef]

28. Mwanamwenge, J.; Loss, S.; Siddique, K.; Cocks, P. Growth, seed yield and water use of faba bean (Vicia faba L.) in a short-season Mediterranean-type environment. Aust. J. Exp. Agric. 1998, 38, 171-180. [CrossRef]

29. Grzesiak, S.; Iijima, M.; Kono, S.; Yamauchi, A. Differences in drought tolerance between cultivars of field bean and field pea. A comparison of drought-resistant and drought-sensitive cultivars. Acta Physiol. Plant. 1997, 19, 349-357. [CrossRef]

30. Abdelmula, A.A.; Link, W.; von Kittltz, E.; Stelling, D. Heterosis and inheritance of drought tolerance in faba bean, Vicia faba L. Plant Breed. 1999, 118, 485-490. [CrossRef]

31. Amede, T.; Kittlitz, E.V.; Schubert, S. Differential drought responses of faba bean (Vicia faba L.) inbred lines. J. Agron. Crop Sci. 1999, 183, 35-45. [CrossRef] 
32. Link, W.; Abdelmula, A.A.; Kittli, E.V.; Bruns, S.; Riemer, H.; Stelling, D. Genotypic variation for drought tolerance in Vicia faba. Plant Breed. 1999, 118, 477-483. [CrossRef]

33. Elshafei, A.A.M.; Amer, M.A.E.; Elenany, M.A.M.; Helal, A.G.A.E. Evaluation of the genetic variability of faba bean (Vicia faba L.) genotypes using agronomic traits and molecular markers. Bull. Natl. Res. Cent. 2019, 43, 106. [CrossRef]

34. Maalouf, F.; Nachit, M.; Ghanem, M.E.; Singh, M. Evaluation of faba bean breeding lines for spectral indices, yield traits and yield stability under diverse environments. Crop Pasture Sci. 2015, 66, 1012-1023. [CrossRef]

35. El Nadi, A. Water relations of beans I. Effects of water stress on growth and flowering. Exp. Agric. 1969, 5, 195-207. [CrossRef]

36. Mwanamwenge, J.; Loss, S.P.; Siddique, K.H.M.; Cocks, P.S. Effect of water stress during floral initiation, flowering and podding on the growth and yield of faba bean (Vicia faba L.). Eur. J. Agron. 1999, 11, 1-11. [CrossRef]

37. Xia, M.Z. Effects of soil drought during the generative development phase of faba bean (Vicia faba) on photosynthetic characters and biomass production. J. Agric. Sci. 1994, 122, 67-72. [CrossRef]

38. Alghamdi, S.S.; Al-Shameri, A.M.; Migdadi, H.M.; Ammar, M.H.; El-Harty, E.H.; Khan, M.A.; Farooq, M. Physiological and molecular characterization of faba bean (Vicia faba L.) genotypes for adaptation to drought stress. J. Agron. Crop Sci. 2015, 201, 401-409. [CrossRef]

39. Adisarwanto, T.; Knight, R. Effect of sowing date and plant density on yield and yield components in the faba bean. Aust. J. Agric. Res. 1997, 48, 1161-1168. [CrossRef]

40. Rharrabti, Y.; Villegas, D.; García del Moral, L.; Aparicio, N.; Elhani, S.; Royo, C. Environmental and genetic determination of protein content and grain yield in durum wheat under Mediterranean conditions. Plant Breed. 2001, 120, 381-388. [CrossRef]

41. Duc, G.; Marget, P.; Esnault, R.; Le Guen, J.; Bastianelli, D. Genetic variability for feeding value of faba bean seeds (Vicia faba): Comparative chemical composition of isogenics involving zero-tannin and zero-vicine genes. J. Agric. Sci. 1999, 133, 185-196. [CrossRef]

42. Alghamdi, S.S. Chemical composition of faba bean (Vicia faba L.) genotypes under various water regimes. Pak. J. Nutr. 2009, 8, 477-482.

43. Schumacher, H.; Paulsen, H.; Gau, A.; Link, W.; Jürgens, H.; Sass, O.; Dieterich, R. Seed, protein amino acid composition of important local grain legumes Lupinus angustifolius L., Lupinus luteus L., Pisum sativum L. and Vicia faba L. Plant Breed. 2011, 130, 156-164. [CrossRef]

44. Singh, S.P. Drought resistance in the race durango dry bean landraces and cultivars. Agron. J. 2007, 99, 1219-1225. [CrossRef]

45. Smith, M.R. Novel Techniques to Improve Yield Quantity and Quality in Common Bean. Ph.D. Thesis, University of Sydney, Sydney, Australia, 2018.

46. Kabbadj, A.; Makoudi, B.; Mouradi, M.; Pauly, N.; Frendo, P.; Ghoulam, C. Physiological and biochemical responses involved in water deficit tolerance of nitrogen-fixing Vicia faba. PLoS ONE 2017, 12, e0190284. [CrossRef]

47. Neugschwandtner, R.; Ziegler, K.; Kriegner, S.; Wagentristl, H.; Kaul, H.-P. Nitrogen yield and nitrogen fixation of winter faba beans. Acta Agric. Scand. B 2015, 65, 658-666. [CrossRef]

48. Guerin, V.; Trinchant, J.-C.; Rigaud, J. Nitrogen fixation $\left(\mathrm{C}_{2} \mathrm{H}_{2}\right.$ reduction) by broad bean (Vicia faba L.) nodules and bacteroids under water-restricted conditions. Plant Physiol. 1990, 92, 595-601. [CrossRef]

49. Sangakkara, U.R.; Hartwig, U.A.; Nösberger, J. Soil moisture and potassium affect the performance of symbiotic nitrogen fixation in faba bean and common bean. Plant Soil 1996, 184, 123-130. [CrossRef]

50. Boyer, J.S. Plant productivity and environment. Science 1982, 218, 443-448. [CrossRef] [PubMed]

51. Lafitte, R.; Blum, A.; Atlin, G. Using secondary traits to help identify drought-tolerant genotypes. In Breeding Rice for Drought-Prone Environments; Fischer, K.M., Lafitte, R., Fukai, S., Atlin, G., Hardy, B., Eds.; International Rice Research Institute: Los Baños, Philippines, 2003; pp. 38-39.

52. Richards, R.A. Physiological traits used in the breeding of new cultivars for water-scarce environments. Agric. Water Manag. 2006, 80, 197-211. [CrossRef]

53. Wery, J.; Silim, S.N.; Knights, E.J.; Malhotra, R.S.; Cousin, R. Screening techniques and sources of tolerance to extremes of moisture and air temperature in cool season food legumes. Euphytica 1994, 73, 73-83. [CrossRef] 
54. Bond, D.; Jellis, G.; Rowland, G.; Le Guen, J.; Robertson, L.; Khalil, S.; Li-Juan, L. Present status and future strategy in breeding faba beans (Vicia faba L.) for resistance to biotic and abiotic stresses. Euphytica 1993, 73, 151-166. [CrossRef]

55. Khazaei, H.; Street, K.; Bari, A.; Mackay, M.; Stoddard, F.L. The FIGS (focused identification of germplasm strategy) approach identifies traits related to drought adaptation in Vicia faba genetic resources. PLoS ONE 2013, 8, e63107. [CrossRef]

56. Ricciardi, L. Plant breeding for resistance to drought. I: Stomatal traits in genotypes of Vicia faba L. Agric. Med. 1989, 119, 297-308.

57. Mahajan, S.; Tuteja, N. Cold, salinity and drought stresses: An overview. Arch. Biochem. Biophys. 2005, 444, 139-158. [CrossRef]

58. Belachew, K.Y.; Stoddard, F.L. Screening of faba bean (Vicia faba L.) accessions to acidity and aluminium stresses. PeerJ 2017, 5, e2963. [CrossRef]

59. Aroca, R.; Porcel, R.; Ruiz-Lozano, J.M. How does arbuscular mycorrhizal symbiosis regulate root hydraulic properties and plasma membrane aquaporins in Phaseolus vulgaris under drought, cold or salinity stresses? New Phytol. 2007, 173, 808-816. [CrossRef] [PubMed]

60. Yang, Z.-B.; Eticha, D.; Albacete, A.; Rao, I.M.; Roitsch, T.; Horst, W.J. Physiological and molecular analysis of the interaction between aluminium toxicity and drought stress in common bean (Phaseolus vulgaris). J. Exp. Bot. 2012, 63, 3109-3125. [CrossRef] [PubMed]

61. Goldman, I.; Carter, T.; Patterson, R. A detrimental interaction of subsoil aluminum and drought stress on the leaf water status of soybean. Agron. J. 1989, 81, 461-463. [CrossRef]

62. Drevon, J.-J.; Alkama, N.; Bargaz, A.; Rodiño, A.P.; Sungthongwises, K.; Zaman-Allah, M. The legume-rhizobia symbiosis. In Grain Legumes. Handbook of Plant Breeding; De Ron, A.M., Ed.; Springer: New York, NY, USA, 2015; pp. 267-290.

63. Shinozaki, K.; Yamaguchi-Shinozaki, K.; Seki, M. Regulatory network of gene expression in the drought and cold stress responses. Curr. Opin. Plant Biol. 2003, 6, 410-417. [CrossRef]

64. Ali, M.B.M.; Welna, G.C.; Sallam, A.; Martsch, R.; Balko, C.H.; Gebser, B.; Sass, O.; Link, W. Association analyses to genetically improve drought and freezing tolerance of faba bean (Vicia faba L.). Crop Sci. 2016, 56, 1036-1048. [CrossRef]

65. Kashiwagi, J.; Krishnamurthy, L.; Crouch, J.; Serraj, R. Variability of root length density and its contributions to seed yield in chickpea (Cicer arietinum L.) under terminal drought stress. Field Crops Res. 2006, 95, 171-181. [CrossRef]

66. Fenta, B.; Beebe, S.; Kunert, K.; Burridge, J.; Barlow, K.; Lynch, J.; Foyer, C. Field phenotyping of soybean roots for drought stress tolerance. Agronomy 2014, 4, 418-435. [CrossRef]

67. Carvalho, I.S.d.; Ricardo, C.P.; Chaves, M. Quality and distribution of assimilates within the whole plant of lupines (L. albus and L. mutabilis) influenced by water stress. J. Agron. Crop Sci. 2004, 190, 205-210. [CrossRef]

68. Chen, Y.L.; Dunbabin, V.M.; Diggle, A.J.; Siddique, K.H.; Rengel, Z. Phosphorus starvation boosts carboxylate secretion in P-deficient genotypes of Lupinus angustifolius with contrasting root structure. Crop Pasture Sci. 2013, 64, 588-599. [CrossRef]

69. Matsui, T.; Singh, B. Root characteristics in cowpea related to drought tolerance at the seedling stage. Exp. Agric. 2003, 39, 29-38. [CrossRef]

70. Chen, Y.; Ghanem, M.E.; Siddique, K.H.M. Characterising root trait variability in chickpea (Cicer arietinum L.) germplasm. J. Exp. Bot. 2016, 68, 1987-1999.

71. Ramamoorthy, P.; Lakshmanan, K.; Upadhyaya, H.D.; Vadez, V.; Varshney, R.K. Root traits confer grain yield advantages under terminal drought in chickpea (Cicer arietinum L.). Field Crops Res. 2017, 201, $146-161$. [CrossRef] [PubMed]

72. Singh, D.; Dikshit, H.K.; Singh, R.; Havey, M. A new phenotyping technique for screening for drought tolerance in lentil (Lens culinaris Medik.). Plant Breed. 2013, 132, 185-190. [CrossRef]

73. Marzougui, A.; Ma, Y.; Zhang, C.; McGee, R.; Coyne, C.; Main, D.; Sankaran, S. Advanced imaging for quantitative evaluation of Aphanomyces root rot resistance in lentil. Front. Plant Sci. 2019, 10, 383. [CrossRef]

74. Abenavoli, M.; Leone, M.; Sunseri, F.; Bacchi, M.; Sorgonà, A. Root phenotyping for drought tolerance in bean landraces from Calabria (Italy). J. Agron. Crop Sci. 2016, 202, 1-12. [CrossRef]

75. Husain, M.; Reid, J.; Othman, H.; Gallagher, J. Growth and water use of faba beans (Vicia faba) in a sub-humid climate I. Root and shoot adaptations to drought stress. Field Crops Res. 1990, 23, 1-17. [CrossRef] 
76. Nagel, K.A.; Putz, A.; Gilmer, F.; Heinz, K.; Fischbach, A.; Pfeifer, J.; Faget, M.; Blossfeld, S.; Ernst, M.; Dimaki, C.; et al. GROWSCREEN-Rhizo is a novel phenotyping robot enabling simultaneous measurements of root and shoot growth for plants grown in soil-filled rhizotrons. Funct. Plant Biol. 2012, 39, 891-904. [CrossRef]

77. Muktadir, M.A.; Adhikari, K.N.; Alam, A.K.M.M.; Uddin, M.S.; Hossain, M.A.; Merchant, A. A high throughput root based phenotyping protocol for drought tolerance in faba bean (Vicia faba L.). In North American Pulse Improvement Association (NAPIA); Michigan State University: East Lansing, MI, USA, 2017.

78. Blum, A.; Mayer, J.; Gozlan, G. Infrared thermal sensing of plant canopies as a screening technique for dehydration avoidance in wheat. Field Crops Res. 1982, 5, 137-146. [CrossRef]

79. Kramer, P.J.; Boyer, J.S. Water Relations of Plants and Soils, 1st ed.; Academic Press: San Diego, CA, USA, 1995; p. 495.

80. O'Neill, P.M.; Shanahan, J.F.; Schepers, J.S. Use of chlorophyll fluorescence assessments to differentiate corn hybrid response to variable water conditions. Crop Sci. 2006, 46, 681-687. [CrossRef]

81. Blum, A. Drought Resistance-Is it really a complex trait? Funct. Plant Biol. 2011, 38, 753-757. [CrossRef] [PubMed]

82. Khazaei, H. Leaf Traits Associated with Drought Adaptation in Faba Bean (Vicia faba L.). Ph.D. Thesis, University of Helsinki, Helsinki, Finland, 2014.

83. Khazaei, H.; O'Sullivan, D.M.; Sillanpää, M.J.; Stoddard, F.L. Use of synteny to identify candidate genes underlying QTL controlling stomatal traits in faba bean (Vicia faba L.). Theor. Appl. Genet. 2014, 127, 2371-2385. [CrossRef] [PubMed]

84. McKinney, N.V.; Schapaugh, W.T.; Kanemasu, E.T. Selection for canopy temperature differential in six populations of soybean. Crop Sci. 1989, 29, 255-259. [CrossRef]

85. Devasirvatham, V.; Tan, D.K.Y. Impact of high temperature and drought stresses on chickpea production. Agronomy 2018, 8, 145. [CrossRef]

86. Kashiwagi, J.; Krishnamurthy, L.; Upadhyaya, H.; Gaur, P. Rapid screening technique for canopy temperature status and its relevance to drought tolerance improvement in chickpea. J. SAT Agric. Res. 2008, 6, 1-4.

87. Zaman-Allah, M.; Jenkinson, D.M.; Vadez, V. Chickpea genotypes contrasting for seed yield under terminal drought stress in the field differ for traits related to the control of water use. Funct. Plant Biol. 2011, 38, 270-281. [CrossRef]

88. Hall, A.E. Phenotyping cowpeas for adaptation to drought. Front. Physiol. 2012, 3, 155. [CrossRef]

89. Biju, S.; Fuentes, S.; Gupta, D. The use of infrared thermal imaging as a non-destructive screening tool for identifying drought-tolerant lentil genotypes. Plant Physiol. Biochem. 2018, 127, 11-24. [CrossRef]

90. Jones, H.G.; Serraj, R.; Loveys, B.R.; Xiong, L.; Wheaton, A.; Price, A.H. Thermal infrared imaging of crop canopies for the remote diagnosis and quantification of plant responses to water stress in the field. Funct. Plant Biol. 2009, 36, 978-989. [CrossRef]

91. Sánchez, F.; De Andres, E.; Tenorio, J.; Ayerbe, L. Growth of epicotyls, turgor maintenance and osmotic adjustment in pea plants (Pisum sativum L.) subjected to water stress. Field Crops Res. 2004, 86, 81-90. [CrossRef]

92. Hsiao, T.C. Plant responses to water stress. Ann. Rev. Plant Physiol. 1973, 24, 519-570. [CrossRef]

93. Pantuwan, G.; Fukai, S.; Cooper, M.; Rajatasereekul, S.; O’Toole, J. Yield response of rice (Oryza sativa L.) genotypes to different types of drought under rainfed lowlands: Part 1. Grain yield and yield components. Field Crops Res. 2002, 73, 153-168. [CrossRef]

94. Turner, N. The role of shoot characteristics in drought resistance of crop plants. In Drought Resistance in Crops with Emphasis on Rice; International Rice Research Institute: Los Baños, Philippines, 1982; pp. 115-134.

95. Levitt, J. Responses of plants to environmental stresses. In Volume II. Water, Radiation, Salt, and Other Stresses, 2nd ed.; Academic Press: London, UK, 1980; p. 607.

96. Jongdee, B.; Fukai, S.; Cooper, M. Leaf water potential and osmotic adjustment as physiological traits to improve drought tolerance in rice. Field Crops Res. 2002, 76, 153-163. [CrossRef]

97. Gebeyehu, S. Physiological Response to Drought Stress of Common Bean (Phaseolus vulgaris L.) Genotypes Differing in Drought Resistance. Ph.D. Thesis, Justus-Liebig-Universität Giessen, Gießen, Germany, 2006.

98. Basu, P.S.; Berger, J.D.; Turner, N.C.; Chaturvedi, S.K.; Ali, M.; Siddique, K.H.M. Osmotic adjustment of chickpea (Cicer arietinum) is not associated with changes in carbohydrate composition or leaf gas exchange under drought. Ann. Appl. Biol. 2007, 150, 217-225. [CrossRef] 
99. Turner, N.C.; Abbo, S.; Berger, J.D.; Chaturvedi, S.K.; French, R.J.; Ludwig, C.; Mannur, D.M.; Singh, S.J.; Yadava, H.S. Osmotic adjustment in chickpea (Cicer arietinum L.) results in no yield benefit under terminal drought. J. Exp. Bot. 2007, 58, 187-194. [CrossRef]

100. Sánchez, F.J.; Manzanares, M.; Andres, E.F.D.; Tenorio, J.L.; Ayerbe, L. Turgor maintenance, osmotic adjustment and soluble sugar and proline accumulation in 49 pea cultivars in response to water stress. Field Crops Res. 1998, 59, 225-235. [CrossRef]

101. Leport, L.; Turner, N.C.; French, R.J.; Tennant, D.; Thomson, B.D.; Siddique, K.H.M. Water relations, gas exchange and growth of cool-season grain legumes in a Mediterranean-type environment. Eur. J. Agron. 1998, 9, 295-303. [CrossRef]

102. Leport, L.; Turner, N.C.; French, R.J.; Thomson, B.D.; Siddique, K.H.M. Physiological responses of cool-season grain legumes to drought in the low rainfall Mediterranean environment of south-western Australia. In Management of Agricultural Drought: Agronomic and Genetic Options; Saxena, N.P., Ed.; Science Publishers Inc.: Enfield, NH, USA, 2003; pp. 163-172.

103. Ricciardi, L.; Polignano, G.B.; Giovanni, C.D. Genotypic response of faba bean to water stress. Euphytica 2001, 118, 39-46. [CrossRef]

104. Lawlor, D.; Cornic, G. Photosynthetic carbon assimilation and associated metabolism in relation to water deficits in higher plants. Plant Cell Environ. 2002, 25, 275-294. [CrossRef]

105. Sinclair, T.; Ludlow, M. Who taught plants thermodynamics? The unfulfilled potential of plant water potential. Funct. Plant Biol. 1985, 12, 213-217. [CrossRef]

106. Kaiser, W.M. Effects of water deficit on photosynthetic capacity. Physiol. Plant. 1987, 71, 142-149. [CrossRef]

107. Siddiqui, M.H.; Al-Khaishany, M.Y.; Al-Qutami, M.A.; Al-Whaibi, M.H.; Grover, A.; Ali, H.M.; Al-Wahibi, M.S.; Bukhari, N.A. Response of different genotypes of faba bean plant to drought stress. Int. J. Mol. Sci. 2015, 16, 10214-10227. [CrossRef] [PubMed]

108. França, M.G.C.; Thi, A.T.P.; Pimentel, C.; Rossiello, R.O.P.; Zuily-Fodil, Y.; Laffray, D. Differences in growth and water relations among Phaseolus vulgaris cultivars in response to induced drought stress. Environ. Exp. Bot. 2000, 43, 227-237. [CrossRef]

109. Rahbarian, R.; Khavari-Nejad, R.; Ganjeali, A.; Bagheri, A.; Najafi, F. Drought stress effects on photosynthesis, chlorophyll fluorescence and water relations in tolerant and susceptible chickpea (Cicer arietinum L.) genotypes. Acta Biol. Crac. Ser. Bot. 2011, 53, 47-56. [CrossRef]

110. Talebi, R.; Ensafi, M.H.; Baghebani, N.; Karami, E.; Mohammadi, K. Physiological responses of chickpea (Cicer arietinum) genotypes to drought stress. Environ. Exp. Biol. 2013, 11, 9-15.

111. Condon, A.G.; Reynolds, M.P.; Rebetzke, G.J.; Ginkel, M.V.A.N.; Richards, R.A.; Farquhar, G.D. Using stomatal aperture related traits to select for high yield potential in bread wheat. In Wheat Production in Stressed Environments; Buck, H.T., Nisi, J.E., Salomón, N., Eds.; Developments in Plant Breeding: Dordrecht, The Netherlands, 2007; Volume 12.

112. Nerkar, Y.S.; Wilson, D.; Lawes, D.A. Genetic variation in stomatal characteristics and behaviour, water use and growth of five Vicia faba L. genotypes under contrasting soil moisture regimes. Euphytica 1981, 30, 335-345. [CrossRef]

113. Belachew, K.Y.; Nagel, K.A.; Poorter, H.; Stoddard, F.L. Association of shoot and root responses to water deficit in young faba bean (Vicia faba L.) plants. Front. Plant Sci. 2019, 10, 1063. [CrossRef]

114. Khazaei, H.; Wach, D.; Pecio, A.; Vandenberg, A.; Stoddard, F.L. Genetic analysis of photosynthesis-related traits in faba bean (Vicia faba L.) for crop improvement. Plant Breed. 2019, 138, 761-769. [CrossRef]

115. Khazaei, H.; Santanen, A.; Street, K.; Stoddard, F.L. Genotypic variation in leaf epicuticular wax quantity in a large faba bean (Vicia faba L.) germplasm collection. Plant Genet. Resour. 2019, 17, 298-300. [CrossRef]

116. Busch, F.A.; Holloway-Phillips, M.; Stuart-Williams, H.; Farquhar, G.D. Revisiting carbon isotope discrimination in $\mathrm{C}_{3}$ plants shows respiration rules when photosynthesis is low. Nat. Plants 2020, 6, 245-258. [CrossRef]

117. Zacharisen, M.; Brick, M.; Fisher, A.; Ogg, J.; Ehleringer, J. Relationships between productivity and carbon isotope discrimination among dry bean lines and $\mathrm{F}_{2}$ progeny. Euphytica 1999, 105, 239-250. [CrossRef]

118. Smith, M.; Wild, B.; Richter, A.; Simonin, K.; Merchant, A. Carbon isotope composition of carbohydrates and polyols in leaf and phloem sap of Phaseolus vulgaris L. influences predictions of plant water use efficiency. Plant Cell Physiol. 2016, 57, 1756-1766. [CrossRef] 
119. Lockhart, E.; Wild, B.; Richter, A.; Simonin, K.; Merchant, A. Stress-induced changes in carbon allocation among metabolite pools influence isotope-based predictions of water use efficiency in Phaseolus vulgaris. Funct. Plant Biol. 2016, 43, 1149-1158. [CrossRef]

120. Clay, D.; Clay, S.; Jackson, J.; Dalsted, K.; Reese, C.; Liu, Z.; Malo, D.; Carlson, C. Carbon-13 discrimination can be used to evaluate soybean yield variability. Agron. J. 2003, 95, 430-435. [CrossRef]

121. Khan, H.; McDonald, G.; Rengel, Z. Zinc fertilization and water stress affects plant water relations, stomatal conductance and osmotic adjustment in chickpea (Cicer arientinum L.). Plant Soil 2004, 267, 271-284. [CrossRef]

122. Hall, A.; Mutters, R.; Hubick, K.; Farquhar, G. Genotypic differences in carbon isotope discrimination by cowpea under wet and dry field conditions. Crop Sci. 1990, 30, 300-305. [CrossRef]

123. Turner, N.C.; Palta, J.A.; Shrestha, R.; Ludwig, C.; Siddique, K.H.M.; Turner, D.W. Carbon isotope discrimination is not correlated with transpiration efficiency in three cool-season grain legumes (pulses). J. Integr. Plant Biol. 2007, 49, 1478-1483. [CrossRef]

124. Bowling, D.R.; Pataki, D.E.; Randerson, J.T. Carbon isotopes in terrestrial ecosystem pools and $\mathrm{CO}_{2}$ fluxes. New Phytol. 2008, 178, 24-40. [CrossRef]

125. Steinfath, M.; Strehmel, N.; Peters, R.; Schauer, N.; Groth, D.; Hummel, J.; Steup, M.; Selbig, J.; Kopka, J.; Geigenberger, P. Discovering plant metabolic biomarkers for phenotype prediction using an untargeted approach. Plant Biotechnol. J. 2010, 8, 900-911. [CrossRef]

126. Caretto, S.; Linsalata, V.; Colella, G.; Mita, G.; Lattanzio, V. Carbon fluxes between primary metabolism and phenolic pathway in plant tissues under stress. Int. J. Mol. Sci. 2015, 16, 26378-26394. [CrossRef]

127. Weckwerth, W. Unpredictability of metabolism-The key role of metabolomics science in combination with next-generation genome sequencing. Anal. Bioanal. Chem. 2011, 400, 1967-1978. [CrossRef] [PubMed]

128. Scherling, C.; Roscher, C.; Giavalisco, P.; Schulze, E.-D.; Weckwerth, W. Metabolomics unravel contrasting effects of biodiversity on the performance of individual plant species. PLOS ONE 2010, 5, e12569. [CrossRef] [PubMed]

129. Soga, T. Capillary electrophoresis-mass spectrometry for metabolomics. In Metabolomics; Weckwerth, W., Ed.; Methods in Molecular Biology ${ }^{\mathrm{TM}}$; Humana Press: New York, NY, USA, 2007; pp. 129-137.

130. Ward, J.L.; Baker, J.M.; Beale, M.H. Recent applications of NMR spectroscopy in plant metabolomics. FEBS J. 2007, 274, 1126-1131. [CrossRef]

131. Zhang, N.; Venkateshwaran, M.; Boersma, M.; Harms, A.; Howes-Podoll, M.; den Os, D.; Ané, J.M.; Sussman, M.R. Metabolomic profiling reveals suppression of oxylipin biosynthesis during the early stages of legume-rhizobia symbiosis. FEBS Lett. 2012, 586, 3150-3158. [CrossRef] [PubMed]

132. Silvente, S.; Sobolev, A.P.; Lara, M. Metabolite adjustments in drought tolerant and sensitive soybean genotypes in response to water stress. PLoS ONE 2012, 7, e38554. [CrossRef]

133. Turner, N.; Jones, M. Turgor maintenance by osmotic adjustment: A review and evaluation. Turgor maintenance by osmotic adjustment: A review and evaluation. In Adaptation of Plants to Water and High Temperature Stress; Turner, N.C., Kramer, P.J., Eds.; John Wiley \& Sons: New York, NY, USA, 1980; pp. 87-103.

134. Serraj, R.; Sinclair, T. Osmolyte accumulation: Can it really help increase crop yield under drought conditions? Plant Cell Environ. 2002, 25, 333-341. [CrossRef]

135. Charlton, A.J.; Donarski, J.A.; Harrison, M.; Jones, S.A.; Godward, J.; Oehlschlager, S.; Arques, J.L.; Ambrose, M.; Chinoy, C.; Mullineaux, P.M. Responses of the pea (Pisum sativum L.) leaf metabolome to drought stress assessed by nuclear magnetic resonance spectroscopy. Metabolomics 2008, 4, 312. [CrossRef]

136. Dias, D.A.; Hill, C.B.; Jayasinghe, N.S.; Atieno, J.; Sutton, T.; Roessner, U. Quantitative profiling of polar primary metabolites of two chickpea cultivars with contrasting responses to salinity. J. Chromatogr. B 2015, 1000, 1-13. [CrossRef]

137. Hernández, G.; Valdés-López, O.; Ramírez, M.; Goffard, N.; Weiller, G.; Aparicio-Fabre, R.; Fuentes, S.I.; Erban, A.; Kopka, J.; Udvardi, M.K. Global changes in the transcript and metabolic profiles during symbiotic nitrogen fixation in phosphorus-stressed common bean plants. Plant Physiol. 2009, 151, 1221-1238. [CrossRef]

138. Teixeira, W.F.; Soares, L.H.; Fagan, E.B.; Mello, S.C.; Reichardt, K.; Dourado-Neto, D. Amino acids as stress reducers in soybean plant growth under different water-deficit conditions. J. Plant Growth Regul. 2020, 39, 905-919. [CrossRef]

139. Watson, B.S.; Bedair, M.F.; Urbanczyk-Wochniak, E.; Huhman, D.V.; Yang, D.S.; Allen, S.N.; Li, W.; Tang, Y.; Sumner, L.W. Integrated metabolomics and transcriptomics reveal enhanced specialized metabolism in Medicago truncatula root border cells. Plant Physiol. 2015, 167, 1699-1716. [CrossRef] [PubMed] 
140. Krasensky, J.; Jonak, C. Drought, salt, and temperature stress-induced metabolic rearrangements and regulatory networks. J. Exp. Bot. 2012, 63, 1593-1608. [CrossRef] [PubMed]

141. Singh, T.; Aspinall, D.; Paleg, L. Proline accumulation and varietal adaptability to drought in barley: A potential metabolic measure of drought resistance. Nat. New Biol. 1972, 236, 188-190. [CrossRef] [PubMed]

142. Aspinall, D. Proline accumulation: Physiological aspects. In Physiology and Biochemistry of Drought Resistance in Plants; Paleg, L.G., Aspinall, D., Eds.; Academic Press: New York, NY, USA, 1981; pp. 243-259.

143. Hayat, S.; Hayat, Q.; Alyemeni, M.N.; Wani, A.S.; Pichtel, J.; Ahmad, A. Role of proline under changing environments. Plant Signal. Behav. 2012, 7, 1456-1466. [CrossRef] [PubMed]

144. Sanchez, D.H.; Schwabe, F.; Erban, A.; Udvardi, M.K.; Kopka, J. Comparative metabolomics of drought acclimation in model and forage legumes. Plant Cell Environ. 2012, 35, 136-149. [CrossRef]

145. Zhang, M.; Wang, L.-F.; Zhang, K.; Liu, F.-Z.; Wan, Y.-S. Drought-induced responses of organic osmolytes and proline metabolism during pre-flowering stage in leaves of peanut (Arachis hypogaea L.). J. Integr. Agric. 2017, 16, 2197-2205. [CrossRef]

146. Venekamp, J.; Lampe, J.; Koot, J. Organic acids as sources for drought-induced proline synthesis in field bean plants, Vicia faba L. J. Plant Physiol. 1989, 133, 654-659. [CrossRef]

147. Ammar, M.H.; Anwar, F.; El-Harty, E.H.; Migdadi, H.M.; Abdel-Khalik, S.M.; Al-Faifi, S.A.; Farooq, M.; Alghamdi, S.S. Physiological and yield responses of faba bean (Vicia faba L.) to drought stress in managed and open field environments. J. Agron. Crop Sci. 2015, 201, 280-287. [CrossRef]

148. Migdadi, H.; El-Harty, E.; Salamh, A.; Khan, M. Yield and proline content of faba bean genotypes under water stress treatments. J. Anim. Plant Sci. 2016, 26, 1772-1779.

149. Rai, V.; Sharma, U. Amino acids can modulate ABA induced stomatal closure, stomatal resistance and $\mathrm{K}^{+}$ fluxes in Vicia faba leaves. Beiträge Zur Biol. Pflanzen 1991, 66, 393-405.

150. Rajagopal, V. The influence of exogenous proline on the stomatal resistance in Vicia faba. Physiol. Plant. 1981, 52, 292-296. [CrossRef]

151. Abid, G.; Ouertani, R.N.; Jebara, S.H.; Boubakri, H.; Muhovski, Y.; Ghouili, E.; Abdelkarim, S.; Chaieb, O.; Hidri, Y.; Kadri, S.; et al. Alleviation of drought stress in faba bean (Vicia faba L.) by exogenous application of $\beta$-aminobutyric acid (BABA). Physiol. Mol. Biol. Plants 2020, 26, 1173-1186. [CrossRef] [PubMed]

152. Rai, V. Role of amino acids in plant responses to stresses. Biol. Plant. 2002, 45, 481-487. [CrossRef]

153. Bouche, N.; Fromm, H. GABA in plants: Just a metabolite? Trends Plant Sci. 2004, 9, 110-115. [CrossRef] [PubMed]

154. Ramesh, S.A.; Tyerman, S.D.; Gilliham, M.; Xu, B. $\gamma$-Aminobutyric acid (GABA) signalling in plants. Cell. Mol. Life Sci. 2017, 74, 1577-1603. [CrossRef]

155. Hatmi, S.; Gruau, C.; Trotel-Aziz, P.; Villaume, S.; Rabenoelina, F.; Baillieul, F.; Eullaffroy, P.; Clément, C.; Ferchichi, A.; Aziz, A. Drought stress tolerance in grapevine involves activation of polyamine oxidation contributing to improved immune response and low susceptibility to Botrytis cinerea. J. Exp. Bot. 2014, 66, 775-787. [CrossRef]

156. Juzoń, K.; Czyczyło-Mysza, I.; Marcińska, I.; Dziurka, M.; Waligórski, P.; Skrzypek, E. Polyamines in yellow lupin (Lupinus luteus L.) tolerance to soil drought. Acta Physiol. Plant. 2017, 39, 202. [CrossRef]

157. Nayyar, H.; Satwinder, K.; Kumar, S.; Singh, K.; Dhir, K. Involvement of polyamines in the contrasting sensitivity of chickpea (Cicer arietinum L.) and soybean (Glycine max (L.) Merrill.) to water deficit stress. Bot. Bull. Acad. Sin. 2005, 46, 333-338.

158. Do, P.T.; Drechsel, O.; Heyer, A.G.; Hincha, D.K.; Zuther, E. Changes in free polyamine levels, expression of polyamine biosynthesis genes, and performance of rice cultivars under salt stress: A comparison with responses to drought. Front. Plant Sci. 2014, 5, 182. [CrossRef]

159. Sadak, M.S.; Abdelhamid, M.T. Influence of amino acids mixture application on some biochemical aspects, antioxidant enzymes and endogenous polyamines of Vicia faba plant grown under seawater salinity stress. Gesunde Pflanz. 2015, 67, 119-129. [CrossRef]

160. Ryan, P.; Delhaize, E.; Jones, D. Function and mechanism of organic anion exudation from plant roots. Ann. Rev. Plant Biol. 2001, 52, 527-560. [CrossRef] [PubMed]

161. Benkeblia, N.; Shinano, T.; Osaki, M. Metabolite profiling and assessment of metabolome compartmentation of soybean leaves using non-aqueous fractionation and GC-MS analysis. Metabolomics 2007, 3, 297-305. [CrossRef] 
162. Arrese-Igor, C. Sucrose synthase and nodule nitrogen fixation under drought and other environmental stresses. Symbiosis 1999, 27, 189-212.

163. Sassi, S.; Aydi, S.; Hessini, K.; Gonzalez, E.M.; Arrese-Igor, C.; Abdelly, C. Long-term mannitol-induced osmotic stress leads to stomatal closure, carbohydrate accumulation and changes in leaf elasticity in Phaseolus vulgaris leaves. Afr. J. Biotechnol. 2010, 9, 6061-6069.

164. Muscolo, A.; Junker, A.; Klukas, C.; Weigelt-Fischer, K.; Riewe, D.; Altmann, T. Phenotypic and metabolic responses to drought and salinity of four contrasting lentil accessions. J. Exp. Bot. 2015, 66, 5467-5480. [CrossRef]

165. Morgan, J.M. Osmoregulation and water stress in higher plants. Ann. Rev. Plant Physiol. 1984, 35, $299-319$. [CrossRef]

166. Rajam, M.V.; Dagar, S.; Waie, B.; Yadav, J.S.; Kumar, P.; Shoeb, F.; Kumria, R. Genetic engineering of polyamine and carbohydrate metabolism for osmotic stress tolerance in higher plants. J. Biosci. 1998, 23, 473-482. [CrossRef]

167. Bianchi, G.; Gamba, A.; Limiroli, R.; Pozzi, N.; Elster, R.; Salamini, F.; Bartels, D. The unusual sugar composition in leaves of the resurrection plant Myrothamnus flabellifolia. Physiol. Plant. 1993, 87, 223-226. [CrossRef]

168. Drennan, P.; Smith, M.; Goldsworthy, D.; van Staden, J. The occurrence of trehalose in the leaves of the desiccation-tolerant angiosperm Myrothamnus flabellifolius welw. J. Plant Physiol. 1993, 142, 493-496. [CrossRef]

169. Paul, M.J.; Primavesi, L.F.; Jhurreea, D.; Zhang, Y. Trehalose metabolism and signaling. Ann. Rev. Plant Biol. 2008, 59, 417-441. [CrossRef]

170. Zacarías, J.J.J.; Altamirano-Hernández, J.; Cabriales, J.J.P. Nitrogenase activity and trehalose content of nodules of drought-stressed common beans infected with effective (Fix $\left.{ }^{+}\right)$and ineffective (Fix ${ }^{-}$) rhizobia. Soil Biol. Biochem. 2004, 36, 1975-1981. [CrossRef]

171. Räsänen, L.A.; Saijets, S.; Jokinen, K.; Lindström, K. Evaluation of the roles of two compatible solutes, glycine betaine and trehalose, for the Acacia senegal-Sinorhizobium symbiosis exposed to drought stress. Plant Soil 2004, 260, 237-251. [CrossRef]

172. López, M.; Herrera-Cervera, J.A.; Lluch, C.; Tejera, N.A. Trehalose metabolism in root nodules of the model legume Lotus japonicus in response to salt stress. Physiol. Plant. 2006, 128, 701-709. [CrossRef]

173. López, M.; Tejera, N.A.; Iribarne, C.; Lluch, C.; Herrera-Cervera, J.A. Trehalose and trehalase in root nodules of Medicago truncatula and Phaseolus vulgaris in response to salt stress. Physiol. Plant. 2008, 134, 575-582. [CrossRef]

174. Iordachescu, M.; Imai, R. Trehalose biosynthesis in response to abiotic stresses. J. Integr. Plant Biol. 2008, 50, 1223-1229. [CrossRef] [PubMed]

175. Merchant, A.; Richter, A.A. Polyols as biomarkers and bioindicators for 21st century plant breeding. Funct. Plant Biol. 2011, 38, 934-940. [CrossRef]

176. Monson, R.K.; Rosenstiel, T.N.; Forbis, T.A.; Lipson, D.A.; Jaeger, C.H. Nitrogen and carbon storage in alpine plants. Integr. Comp. Biol. 2006, 46, 35-48. [CrossRef]

177. Merchant, A.; Adams, M.A.; Richter, A.; Popp, M. Targeted metabolite profiling provides a functional link among eucalypt taxonomy, physiology and evolution. Phytochemistry 2006, 67, 402-408. [CrossRef]

178. Dumschott, K.; Dechorgnat, J.; Merchant, A. Water deficit elicits a transcriptional response of genes governing D-pinitol biosynthesis in soybean (Glycine max). Int. J. Mol. Sci. 2019, 20, 2411. [CrossRef]

179. Ford, C.W. Accumulation of low-molecular weight solutes in water-stressed tropical legumes. Phytochemistry 1984, 23, 1007-1015. [CrossRef]

(C) 2020 by the authors. Licensee MDPI, Basel, Switzerland. This article is an open access article distributed under the terms and conditions of the Creative Commons Attribution (CC BY) license (http://creativecommons.org/licenses/by/4.0/). 